\section{推进沉浸式数据交互的虚拟现实技术 VIRTUAL REALITY FOR IMMERSIVE DATA INTERACTION}

\section{1 反思过去}

将与特定位置相关的准确记录或数据集融人景观设计之中的传 统由来已久, 在其影响下, 地理信息系统 (GIS) 于1963年问世 ${ }^{\mathbb{D}}$ 。随 后，伊恩 $\cdot \mathrm{L} \cdot$ 麦克哈格在其著作《设计结合自然》中又将该系统提升 到了新的高度。在愈加复杂的环境挑战面前, 景观设计通常被置于与 生态系统服务相同的层级。因此，在规划过程中，相较于场地特征、 场地内在特性以及未来使用人群等数据, 与 “蓝色和绿色基础设施” 相关的数据往往更具影响力。

在《设计结合自然》出版 50 年后的今天，当我们再次审视这本书 的核心思想时, 会惊讶地发现尽管我们已取得了巨大的技术进步, 记 录了不计其数的数据集, 却还是未能结合景观本身所具有的巨大力量 和演变趋势进行设计 ${ }^{[1]}$ 。正如理查德 - 韦勒、弗雷德里克 - 斯坦纳和比 利- 弗莱明总结的那样, “麦克哈格意在指出, 开发和改造地球的最 佳方式是在规划设计时充分考虑生态与景观特性。”[2]

\section{2 数据体验}

当前, 有关虚拟现实 (VR) 与混合现实 (MR) 领域中人类与大规 模环境数据流进行交互的开创性应用研究正在持续进行中, 国际上对 于 “大数据” 主题的探讨也常基于这一研究的部分项目展开 ${ }^{[3]}$ 。该研究 尤其聚焦于时间、交互、视觉和听觉等元素。

城市区域是实现可持续发展的重要战场, 然而, 面对景观与城市 中层出不穷的复杂挑战, 能够与之抗衡的规划设计方法仍显得捉襟见 肘。与此同时, 人工智能以及 $V R$ 和增强现实 (AR) 等沉浸式工具正 在迅猛发展, 并逐渐成为我们日常生活的一部分。MR技术为更好地理

1) 由罗杰汤姆林森开创性发起、筹划并建立的加拿大地理信息系统（CGIS），促成了世界上首个计算 机化GIS于1963年问世。

https://doi.org/10.15302/J-LAF-20190216 收稿时间 RECEIVED DATE / 2019-04-13 中图分类号 / TP242 文献标识码/B

皮娅 · 弗里克

芬兰阿尔托大学景观设计与都市主义计算方法研究室实践应用教授

摘要

在这个由技术发展塑造的时代，现实与虚拟 世界的边界正在逐渐消融, 当下我们面临的挑战 是如何重新定义虚拟现实与混合现实在景观设计 领域应用的潜力。基于对此类技术的主要应用领 域的批判性分析, 可以得知当前的研究重点是优 化虚拟空间的三维可视化与导航系统。在专业实 践, 特别是智能建筑行业中, 混合现实工具正在 被越来越多地应用于市场测试与设计决策的商务 沟通。

迄今为止，沉浸式环境在景观设计领域的 应用仍缺乏以人为中心的数据交互与空间感知研 究。由芬兰阿尔托大学景观设计与都市主义计算 方法研究室实践应用教授皮娅·弗里克带领的团 队正致力于研究全新的沉浸式协同设计方法，以 为参与式设计过程提供极具价值的新型研究路 径。由此, 混合现实的应用可突破常规用途, 并 基于数据信息处理促进跨学科沉浸式互动空间的 创建。本文展示的研究与教学成果反映了全球对 “数字人文一大数据与以人为中心的设计” 这 一宏大议题的探讨。

\section{关键词}

虚拟现实; 混合现实; 增强现实; 景观设计; 参 与式设计；沉浸式互动；数据分析
Pia FRICKER*

Professor of Practice for Computational Methodologies in Landscape Architecture and Urbanism at Aalto University

*Corresponding Author A Al-00076, Aalto. Fintand Email: pia.fricker@aalto.fi

\section{ABSTRACT}

In a time shaped by technological developments dissolving the boundaries between the real and the virtual world, we are challenged to newly define the potentials of virtual and mixed reality in the field of landscape architecture. Critical analyses of the primary application areas of these technologies show that the current focus mostly lies on the optimization of 3D visualization and navigation in virtual space. Within professional practice, mixed reality tools are increasingly being used to test and communicate design decisions, for marketing purposes, and more often, within the smart building industry as well.

Thus far, the incorporation of immersive environments in landscape architecture is lacking research on human-centered data interaction and the perception of space. At Aalto University, Finland, the team of Pia Fricker, Professor of Practice for Computational Methodologies in Landscape Architecture and Urbanism, researches new immersive co-design methodologies to introduce new meaningful trajectories for participatory processes. Mixed reality applications are thus extended beyond common and conventional uses to help create multidisciplinary immersive interactive spaces using data informed processes. The research and teaching results showcased in the article address international discourse on the larger theme of "Digital Humanism - Big Data and HumanCentered Design."

\section{KEY WORDS}

Virtual Reality; Mixed Reality; Augmented Reality; Landscape Architecture; Participatory Design; Immersive Interaction; Data Analysis 
解、设计和管理周遭环境带来了空前的机遇。这些技术的巨大潜力在 于其能够将人们对于环境的不同构想图示化, 并支持有着不同学科、 专业和背景的人士对此进行探讨。此外, 与MR技术相整合的新技术能 够更好地处理抽象数据集, 不仅可直接实现数据的可视化, 而且能够 在参与式过程这一广泛主题下将协同设计提升至新的高度 ${ }^{[4]}$ 。

以上发展现状不仅与麦克哈格的核心思想密切相关, 也与阿兰 伯格的新近设计实践有着重要关联, 他提出, “我们必须利用设计智 慧和强大的新型分析工具, 创造性地恢复由短期经济模式、左右摇摆 的政治决策、临时性开发、公众参与缺失, 以及尚待完善的环境政策 所导致的碎片化区域景观系统。” ${ }^{[5]}$

\section{3 基于MR的协同式设计}

沉浸式技术使不同背景的人们可以产生直观互动; 这种互动仿佛 是在现实环境中发生的自然过程 ${ }^{[6]}$ 。基于 $\mathrm{VR}$ 和 $\mathrm{AR}$ 提供的可靠原型, 我 们可以实现技术的快速迭代。在可预见的未来, VR 设备和各种在线实 时应用程序将成为我们日常生活的一部分。

然而, 直到现在, 融合了VR技术的现有参与式系统仍无法将实际 发现整合到互动过程之中, 且无法将某一场景的潜在特质或参与者的 沉浸式关联植人场地历史。这主要是由于当前应用于参与式过程中的 $V R$ 与 AR相结合的方法一直以来都将关注点放在了沉浸式空间体验的打 造, 尤其是未来场景的精细化建模上。

与当前力求在VR中营造逼真视觉效果和攻克技术壁垒的趋势不 同, 皮娅- 弗里克教授重点关注发展协同设计方法, 意在将人工智 能、机器人技术、VR和数据可视化等不同主题整合至一个平台之上。 2016年，在关于该课题的首批研讨会中的讨论框架中，就已提出了核 心的引导性问题, 这些问题也被用作更高层级的框架, 并在弗里克教
授的项目中得到了解决。

在将创造性应用整合到大规模规划设计活动中时, 虽然可以得到 相应技术的支持, 但仍存在以下问题: 如何将整合了大数据、VR/AR技 术及机器人技术的共生体用于挖掘景观设计与城市设计专业的潜能? 通过在虚拟空间中置人数据, 我们创造出了怎样的体验? 如何通过整 合VR开辟新的参与式系统或协同系统, 以理解未来工作的复杂性和可 能性 (即结合气候变化挑战、国内与国际社会挑战等) ? 这些均与数 据集相关而又彼此关联的问题又将如何为气候变化议题下的景观设计 领域提供新的优势, 以拓展并强化我们对韧性、可持续性及生态技术 等概念的理解? ${ }^{[7]}$

跨学科是该系列研究的重点。阿尔托虚拟影院实验室 ${ }^{2}$ 的一部分研 究员来自电影领域, 通过与他们进行合作, 研究团队获得了更多有关 叙事手法的经验, 并认识到 “讲好一个故事” 的重要性。通过监测 “叙 事电影对大脑活动和眼球运动所具有的显著控制作用” ${ }^{[8]}$, 希恩斯 - 艾 利沙卡指出, 认知神经科学可以揭示出这种叙事所起到的效用。人类认 知神经科学系统各分支领域 (如感知、体验、记忆和决策) 的整合, 以 及极具价值的以未来为导向的可持续城市设计与景观设计方法, 为正 在进行中的该项研究提供了有力支持。通过整合研究方法, 分析包括 脑电图 $(\mathrm{EEG})^{\sqrt[3]{ }}$ 、皮肤电反应 $(\mathrm{GSR})^{\oplus}$ 在内的生物信号等用户体验数 据, 并将与抽象数据的交互视作重新畅想城市未来的契机, 可赋予相关 应用全新的可能性。[9]

聚类和分类等机器学习技术以及深度学习神经网络已被应用于大 数据分析中, 但它们在景观及城市规划领域辅助设计和社区决策的潜 能仍有待开发 ${ }^{[10]}$ 。在本研究探讨的测试案例中, 团队利用实时数据分 析检验设计场景, 并基于实况卫星数据或野外调查数据优化设计决 策。通过创建与该任务相匹配的特殊的VR/AR环境, 可促进上述内容 的整合 ${ }^{[1]}$ 。
(2) 虚拟影院实验室 $(\mathrm{VCL})$ 是面向阿尔托 ( 没构, 为研究人员、 沿机构, 为㙂人员、 教育工作者和业界专业 人士提供了交流平台。 $V C L$ 的研究重点是为新 兴媒体技术方面的内容 创作拟定工作流程, 以 及为如何使用这些工具 叙事和传递情感制定策 叙事和传递情感制定策 略, 从而加速推动新技
术在行业内的应用。

(3) 脑电图 (EEG) 是一种 非侵入式神经影像技 术, 即通过头皮电极测 量脑压波动。这些波动 由大量同时活动且方向 相似的皮层细胞的突

后电位变化所引起。 皮肤电反应 (GSR)， 也被称为皮肤电活动 （EDA）或皮肤电传导 ( SC ), 是指对皮肤电 特性 (如由于出汗使人 体发生变化从而引起电 导) 的持续变化所进行 的测量。

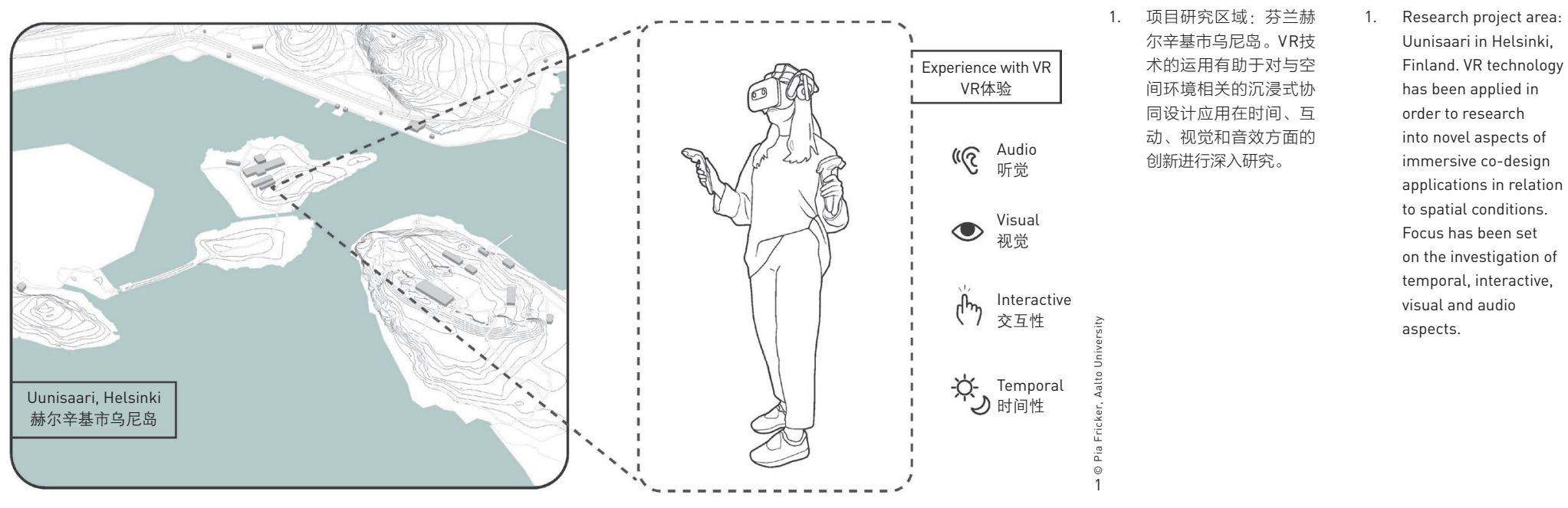


2. 该项目聚焦于探索迭代设 计过程中人们在 $V R$ 环境 中进行交互式体验的型 旬推移而演变。项目从感 知、氛围和视线的动态变 化等维度, 对景观体验进 行了研究。此外, 项目运 用VR技术来探究互动性 设计元素的影响与潜力, 试图回答“如何运用沉浸

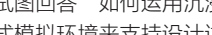
程” “为了达到恰当的抽 象化程度, 使研究重点放 在整体设计 (而非建模) 上, 哪些工作流程是必要 的”等问题。该项目由迈 亚·约恩苏和劳拉·莱多芬 尼完成。

2-1. 互动式空间系统设计方案 2-2. 可能生成的景观视角总览

2-3. 协同设计阶段: 根据使用 者和设计师的反馈进行的 几轮设计调整
2. This project concentrates on the potential of human interaction in VR in relation to the iterative design process. As landscape is a dynamic system that changes through seasons and over time, the experience of a landscape was researched under the focus of

and dynamic changes

of views. In addition,

the project used VR

understand the impact and potential of an interactive design element. Questions addressed included

"how can the immersive

simulated environment

be experienced to support

the design process?"

and "which workflows

are needed in order to

create the right level

of abstraction, so that

the focus will be on the

overall design, rather than

modeling aspects?" This

project is conducted by

Maija Joensuu and Laura

Lehtovuri.

2-1. Scheme of interactive

spatial system

2-2. Overview of possible

generated landscap

views

2-3. Co-design phase: iteration

of design adjustment

according to user and

designer feedback. (ii)
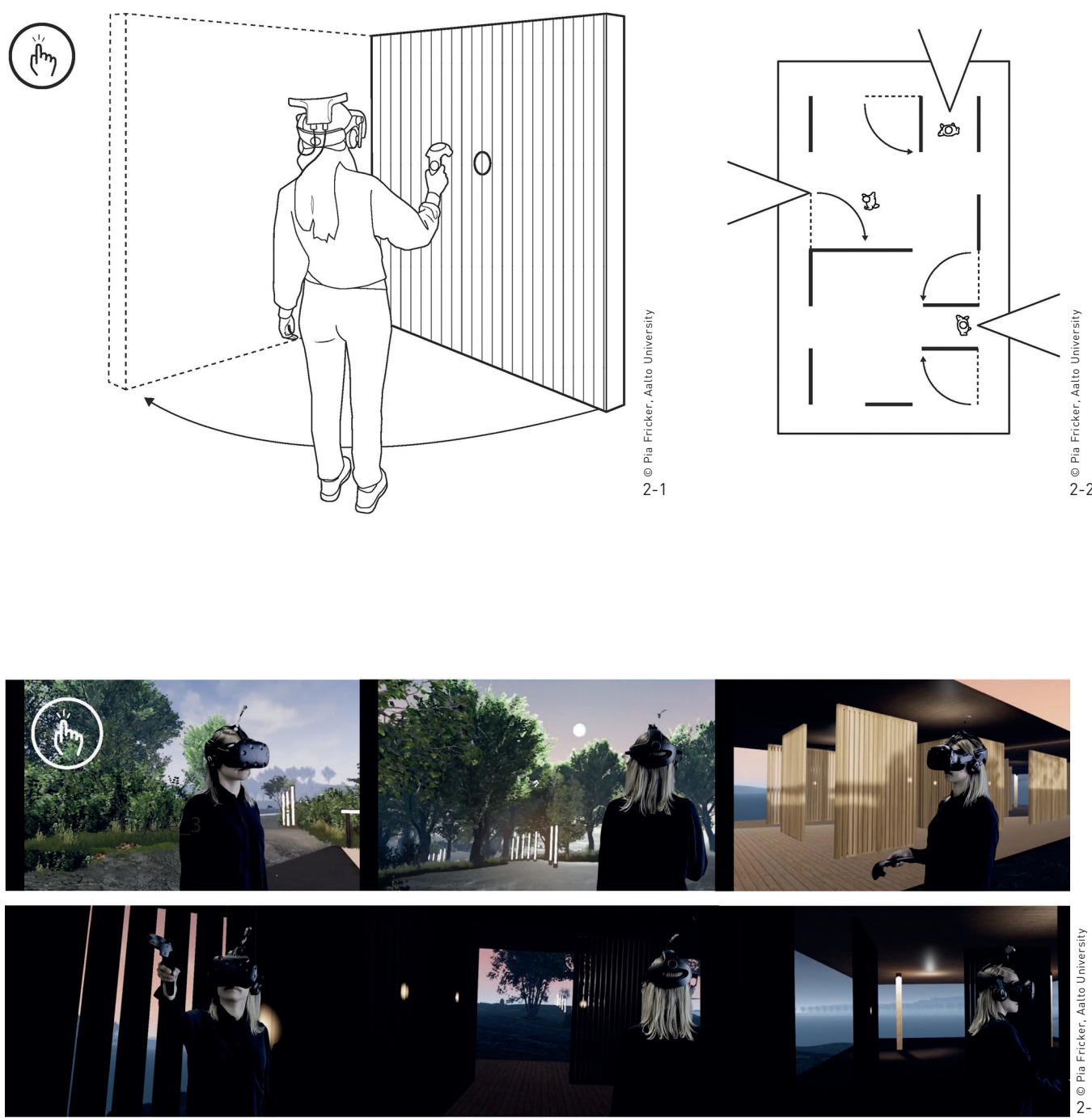

\section{4 展望}

先进的空间现实技术旨在开辟新的模拟途径, 将参与式过程融人 环境设计与城市开发之中, 进而为社会与环境挑战提供可持续的解决 方案, 以重塑城市未来。该研究项目的创新之处在于能够使人们直接 且轻松地参与设计过程并发挥积极作用, 从而加强各方的未来福祉。 研究团队下一步将聚焦于机器人及物理增强技术, 它们在众多面临复 杂决策的学科中发挥着关键作用, 例如通过数字化制造技术, 普通工 匠也可以制作复杂的机械零件 ${ }^{[12]}$ 。景观与城市设计领域所面临的通常都 是涉及上百个参数及要素的复杂决策。在这一情况下, 机器人可以连 接VR/AR环境与物理世界, 以便利用城市与景观增强模型等直观的交互
式空间界面 ${ }^{[4][13]}$ 。通过三维扫描仪和相机可以将由人类行为或机器驱动 所激发的模型变化反馈到数字环境中，从而实现将实时变化融人设计 过程。研究并设计此类增强设计环境原型, 将真实世界的相关数据融 人设计和决策过程之中, 将会是下一阶段研究的主要目标。LAF

致谢

这一正在进行中的研究由芬兰阿尔托大学景观设计与都市主义计算方法研究室带领的数字景观设计小组主 持开展。本文所展示的内容是 “进入混合现实”与 “虚拟现实中的声音与点云交互” 这两个项目的研究成 果。由此得到的概念、工作流程和理论问题为该领域的最新研究奠定了基础

衰心感谢积极参与本次研究的学生们。同时感谢劳里 - 莱姆梅恩雷迪和米科 ·维克利提供的重要理论及教学 支持, 感谢蒂娜・赛波来贾克在图像编辑方面给予的帮助, 并特别感谢为本次研究带来极大启发的米科・萨 姆斯教授和希恩斯・艾利沙卡，以及阿尔托大学建筑系主任佩卡・海基宁教授。 

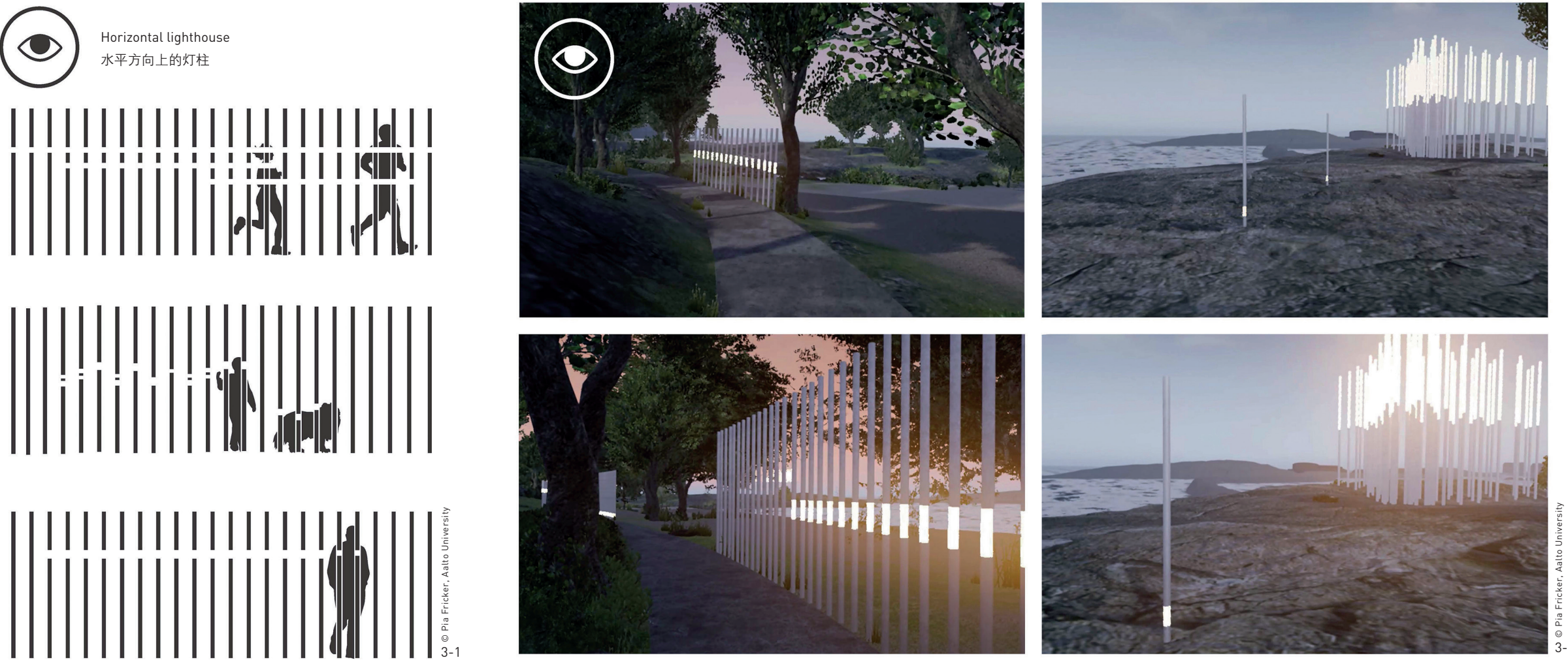

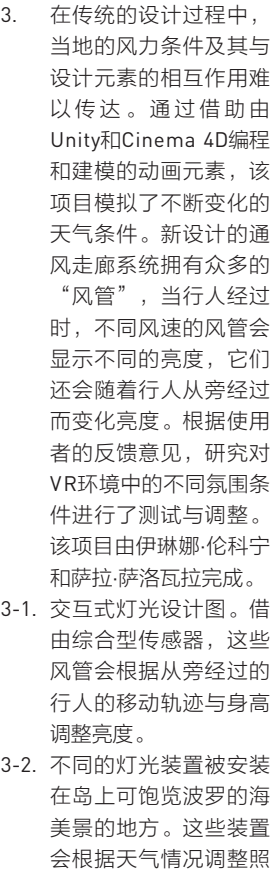

在传统的设计过程中, 当地的风力条件及其与 设计元素的相互作用难 以传达。通过借助由

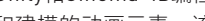
项目模拟了不断变化的 天气条件。新设计的通 风走廊系统拥有众多的 “风管”, 当行人经过 时, 不同风速的风管会 显示不同的亮度，它们 还会随着行人从旁经过 而变化亭度。柦坦使用 者的聩音见, 研究对 者的反馈意见, 研究对 R环境中的不同氛围条 件进行了测试与调整。 该项目由伊琳娜、伦科宁 和萨拉·萨洛瓦拉完成。

3-1. 交互式灯光设计图。借 由综合型传感器, 这些 风管会根据从旁经过的 行人的移动轨迹与身高 调整亮度。

3-2, 不同的灯光装置被安装 在岛上可饱览波罗的海 美景的地方。这些装置 会根据天气情况调整照 明方式。

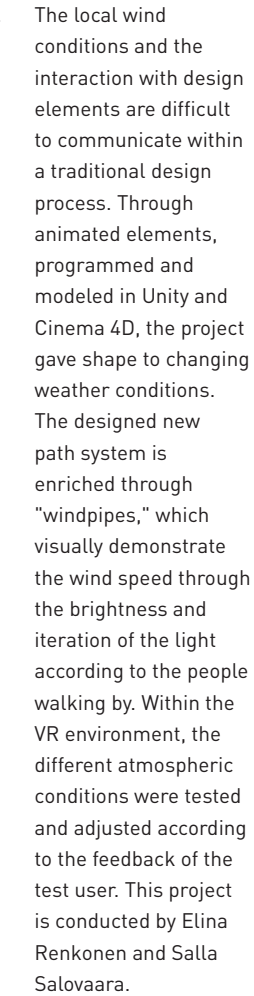

\section{Reflection on the Past} integrated sensors, the light is reacting to the the perso (1) igh sethings or he installation at the most scenic point of the island, with open view lights are changing lights are changing to the we

The integration of site specific, accurate, and relevant records or data sets in landscape architecture has a long tradition. It led to the establishment of the Geographic Information System (GIS) in $1963^{(1)}$, which was raised to the next level by Ian L. McHarg in his book Design with Nature. Fostered by continually more complex environmental challenges, landscape architecture is often put on the same level as the term "ecosystem services." As a result, data from the area of "blue and green infrastructure" tends to have more influence in the planning process than data relative to the character and inherent characteristics of a site and its future user groups.

When one examines the central message of Design with Nature today almost 50 years after its publication, it is remarkable to note that despite all technological advancements and recordings of endless data sets, we have not been able to design together with the immense power and flow of the landscape ${ }^{[1]}$. As concluded by Richard Weller, Frederick Steiner, and Billy Fleming: "McHarg meant that the way we occupy and modify the earth is best when it is planned and designed with careful regard to both the ecology and the character of the landscape." ${ }^{[2]}$
Roger Tomlinson's pioneering work to
initiate, plan, and develop the Canada Geographic Information System (CGIS) resulted in the first computerized GIS in the world in 1963. 


\section{Let Us Experience Data}

Within the international discourse on the theme of Big Data, the introduced projects are part of an ongoing research into visionary application fields of human interaction with large-scale environmental data flow in the realm of Virtual Reality (VR) and Mixed Reality $(\mathrm{MR})^{[3]}$. Special focus is set on the research of temporal, interactive, visual, and audio elements.

While urban areas play a key role in attaining sustainable development, planning and design is struggling with insufficient methods to deal with the increasingly complex emerging challenges to landscape and cities. Artificial Intelligence (AI) in connection with immersive tools such as VR and Augmented Reality (AR) are rapidly emerging as a part of our daily lives. The MR technology offers an unprecedented opportunity to understand, design, and manage our surroundings better. They possess great potential for illustrating alternative visions of our environment and supporting discussions of the implications between people of different disciplines, professions, and backgrounds. Moreover, through the integration of MR, new technologies are given new possibilities of dealing with abstract data sets, not only to gain direct access to data visualization, but also to be able to define a new level of co-design in the broad theme of participative processes ${ }^{[4]}$.
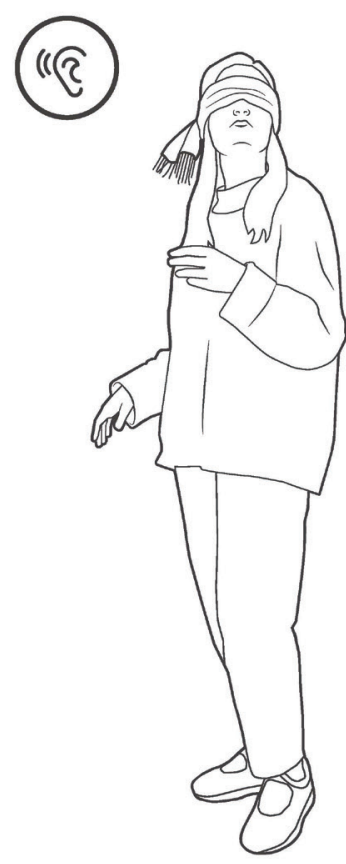

Perception through sound 通过听觉进行感知

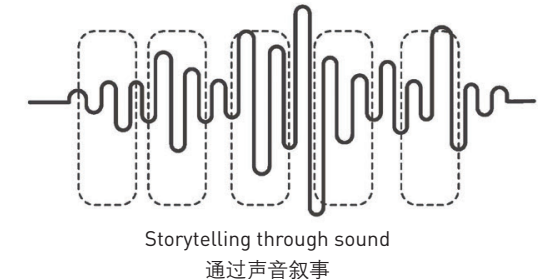

通过声音叙事

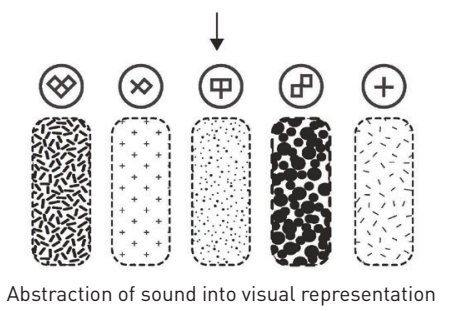

将声音抽象为视觉表现

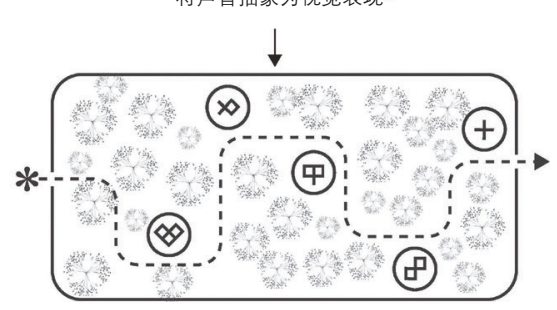

Arrangement into an abstract landscape 将其置入抽象的景观之中
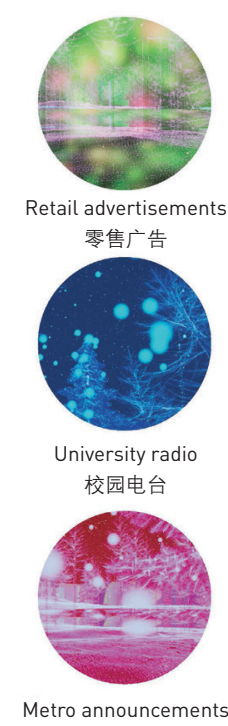
地铁通告

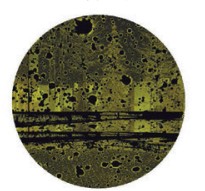

Public radio streaming 公共广播电台
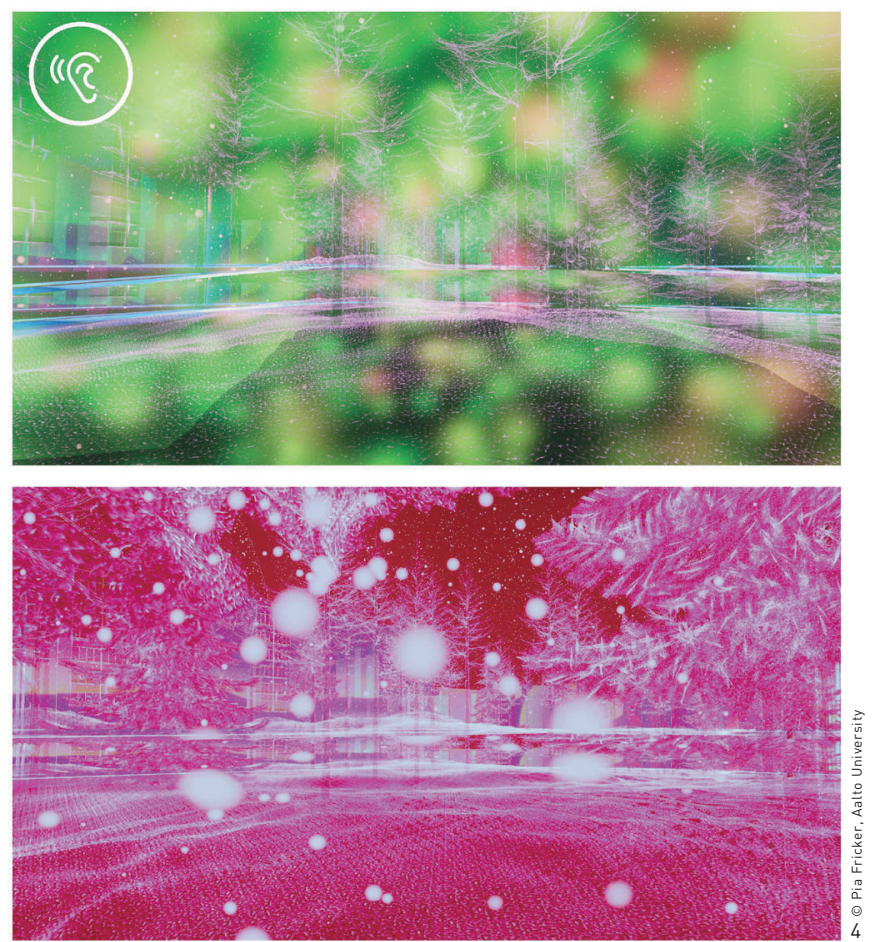


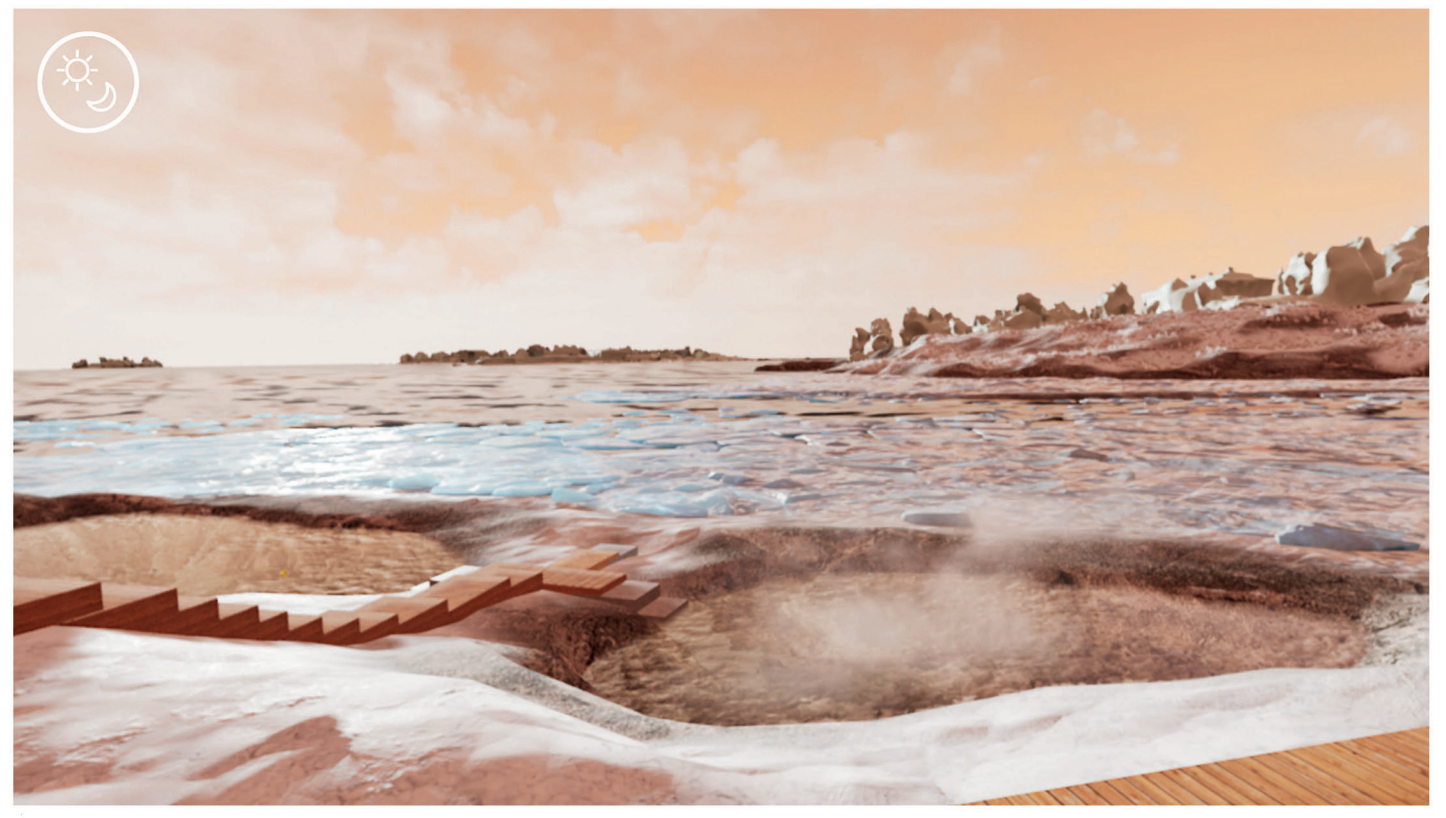

5. VR offers the

opportunity to discuss

the temporal Iseasons,

day-night) element

of landscape design.

Through the integration

of parametric models

of vegetation within

Cinema 4D, the

special qualities of the

landscape design can

be experienced and

be experienced and

evaluated. This project is conducted by Eeva-
Maija Ekman and Heidi Seesto.
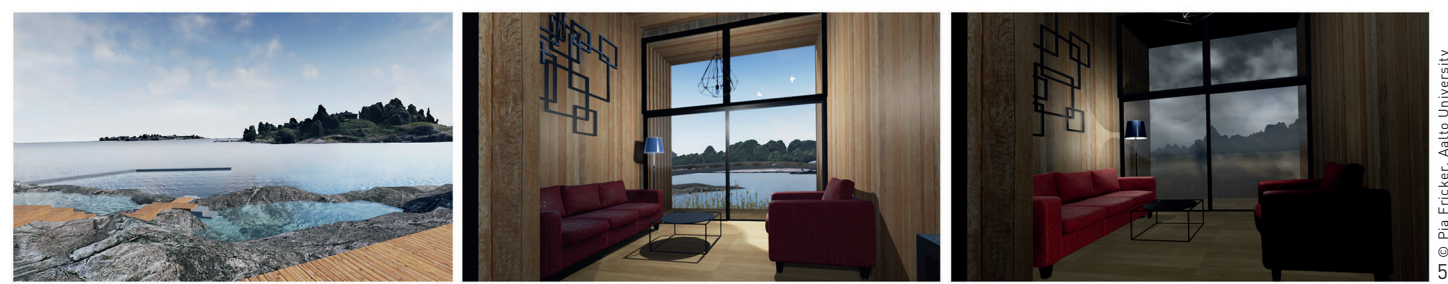

This is closely connected to the central message of McHarg and is placed in critical relation to current practice by Alan Berger: "We must deploy design intelligence with powerful new analytical tools to creatively recover pieces of regional landscape systems left in the wake of short-term economic schema, political indecision, ad hoc development, a negligent public, and flawed environmental policy." ${ }^{[5]}$

\section{MR-Based Collaborative Design}

Immersive technologies allow for an intuitive interaction of people of various backgrounds; the interaction is comparable with natural processes in real environments ${ }^{[6]}$. VR and AR do as well enable us to have more informed prototyping, allowing iterations with little loss of time. Within the foreseeable future, the usage of VR devices and different kinds of online real-time apps will be part of our daily life.

Up until now, the developed participatory systems integrating VR could not contribute real findings into the process and do not transmit any hidden layers of a place or an immersive connection to the history of the place. That is primarily due to the fact that current methods for the integration of VR and AR for participative processes previously placed their focus on immersive spatial experience, especially on the detailed modeling of future scenarios.

Contrary to current trends, the overcoming of technical hurdles of photorealistic visualization in VR, professor Pia Fricker focuses on the development of co-design methods, which combine different themes like AI, robotics, VR, data-visualization together in one platform. Already in 2016 within the framework of one of the first research colloquiums on the subject, central guiding questions were developed, which were used as a higher-level framework and addressed in professor Fricker's project as well.

Technologies are available where the innovative application areas can coexist within large-scale planning and design activities. However, the questions remain: how can the symbiosis of the themes of big data, VR / AR, and robotics capture new possibilities for the profession of Landscape Architecture and urban design? What kinds of experiences do we create through the engagement of data in virtual spaces? How can we achieve a new way of participatory 
or collaborative systems by integrating VR in order to understand the complexity and potential of the future task, i.e. integrating the challenges of climate change, national and international societal challenges, etc.? How do these interrelated questions on data sets offer new vantage points on the landscape architectural ramification of climate change, extending and amplifying our understanding of ideas such as resiliency, sustainability, and ecotechnology? ${ }^{[7]}$

One important part in this research constellation is the interdisciplinary aspect. The collaboration with researchers out of the area of film, being part of Aalto's Virtual Cinema Lab ${ }^{2}$, opens up to the experience in the area of storytelling and their importance. Synes Elischka points out that cognitive neuroscience reveals the power of storytelling by measuring that narrative "films can exert considerable control over brain activity and eye movements. ${ }^{\not 8]}$ The integration of the field of aspects of the human cognitive neuroscience system, such as perception, experience, memory, and decision making for the development of meaningful future-oriented methods for sustainable urban design and landscape architecture are elements of the ongoing research. The integration of research methods to analyze user experience data, including data from bio-signals such as electroencephalography $(\mathrm{EEG})^{(3}$, Galvanic Skin Response $(\mathrm{GSR})^{\circledR}$, opens up a new dimension in application possibilities, as they have opened up a new understanding of interaction with abstract data as a source to re-imagine alternative futures ${ }^{[9]}$.

Although machine learning techniques, like clustering and classification, and the use of neural nets in deep learning have been already employed in big data analysis, their potential for aiding design and community decisions in landscape and urban planning is still largely unexplored ${ }^{[10]}$. Within the test cases explored in the research, workflows make use of real-time data analysis to test out design scenarios and make informed decisions based on current real-world data acquired from satellites or gathered on the field. Thus, this integration is facilitated through special VR / AR environments made fit for the task ${ }^{[11]}$.

\section{Outlook}

The resulting cutting-edge spatial reality aims to open up new ways of simulation and integrating of participatory processes in environmental design and urban development to give sustainable answers to societal and environmental challenges and to shape the future. The novelty in the research project lies in the direct and effortless involvement of humans into the design process to empower them to play an active role in the process and enhance their future wellbeing. The next step will be the investigation of robotics and related technologies in physical augmentation, as they play a key role in many disciplines which require complex decision-making, for example digital fabrication techniques which enable crafters to produce complex mechanical parts ${ }^{[12]}$. Complex decision-making involving sometimes hundreds of parameters and key players is inherent in the landscape and urban design field. In this context, robotics can provide a link between the VR / AR environment and the physical world to utilize interactive and intuitive spatial interfaces like augmented urban and landscape models ${ }^{[4][13]}$. Changes done on these models through human interaction or machine actuation can be fed back into the digital environment through 3D scanners and cameras and enable real-time integration in the design process. Investigating and prototyping these kinds of augmented design environments, which integrate relevant real-world data in the design and decision-making process, would be the primary research goal in the next stage. LAF

\section{ACKNOWLEDGEMENTS}

This ongoing research is conducted by the Digital Landscape Architecture group at the Professorship for Computational Methodologies in Landscape Architecture and Urbanism at Aalto University, Finland. The showcased projects are results of the research-oriented studies "Entering Mixed Reality" and "Interaction between Sound and Pointclouds in Virtual Reality." The developed concepts, workflows, and theoretical questions form the basis for current research in this area.

The author would like to thank the highly motivated students participating in the studios. Lauri Lemmenlehti and Mikko Vekkeli for their great conceptual and teaching support, Tina Cerpnjak for her image editing support, and special thanks to professor Mikko Sams and Synes Elischka, who have been a great source for inspiration, as well as to the head of the Architecture Department at Aalto University. professor Pekka Heikkinen.

\section{REFERENCES}

[1] McHarg, I. L. (1995). Design with Nature. New York: John Wiley \& Son

[2] Weller, R., Steiner, F., \& Fleming, B. In. d.). What does it mean to design with nature now? A collection of responses to a McHarg-inspired question. Retrieved from https://mcharg.upenn.edu/conversations/ what-does-it-mean-design-nature-now

[3] Fricker, P., \& Munkel G. (2015). Data Mapping: Interactive Big Data Visualization in Landscape Architecture. In E. Buhmann (Ed.), Peer Reviewed Proceedings Digital Landscape Architecture 2015: at Architecture. In E. Buhmann (Ed.), Peer Reviewed Proceedings Digital Land

[4] Huang. W. D., Alem, L., \& Livingston, M. A. (Eds.) (2012). Human Factors in Augmented Reality Environments. London: Springer.

[5] Berger, A. (n. d.). What does it mean to design with nature now? A collection of responses to a McHarginspired question. Retrieved from https://mcharg.upenn.edu/conversations/what-does-it-mean-designnature-now

[6] Mark, B., Elischka, S., Satu, L., Siru, S., Nanna, S., Dung, V. B. T., \& Hu, Z. (2014). Power to the people: Media users' capabilities and motivations to influence content production and distribution. In Y. Neuvo, E. Ormala, \& M. Kuikka (Eds.J), Bit Bang 6: Future of Media (pp. 11-41). Helsinki: Aalto University's Multidisciplinary Institute of Digitalisation and Energy (MIDE), Aalto University.

[7] Fricker, P. (2018). The Real Virtual or the Real Real: Entering Mixed Reality. Journal of Digital Landscape Architecture, (3), 414-421.

[8] Hasson, U., Landesman, O., Knappmeyer, B., Vallines, I., Rubin, N., \& Heeger, D. J. (2008) Neurocinematics: The Neuroscience of Film. Projections, 2(1), 1-26.

[9] Busch, N. A., Dubois, J., \& Vanrullen, R. (2009). The phase of ongoing EEG oscillations predicts visual perception. Journal of Neuroscience, 29(24), 7869-7876.

[10] Dourish, P. (2001). Where the Action is: The Foundations of Embodied Interaction. Boston: MIT Press.

[11] Mihelj, M., Novak, D., \& Begus, S. (2013). Virtual Reality Technology and Applications. Heidelberg: Springer.

[12] Dalton, N. S., Schnadelbach, H. Wiberg, M. \& Varoudis, T. (Eds.) (2016). Architecture and Interaction: Human Computer Interaction in Space and Place. Switzerland: Springer

[13] Bainbridge, W. S. (2011). The Virtual Future. London: Springer. 